\title{
14. CHEMICAL AND ISOTOPIC COMPOSITION OF INTERSTITIAL WATER FROM DEEP SEA DRILLING PROJECT SITES 533 AND 5341
}

\author{
Peter D. Jenden, Institute of Geophysics and Planetary Physics and Department of Earth and Space Sciences, \\ University of California at Los Angeles, Los Angeles, California \\ and \\ Joris M. Gieskes, Scripps Institution of Oceanography, La Jolla, California
}

\begin{abstract}
Low salinities and strong opposing fluctuations between chlorinity and interstitial water $\delta^{18} \mathrm{O}$ and $\delta \mathrm{D}$ characterize the region of gas-hydrate occurrence at Site 533. In addition to the hydrate recovered from $243 \mathrm{~m}$ sub-bottom, thin, diffuse layers of hydrate composing about $10 \%$ of the total pore space may have been cored around $290 \mathrm{~m}$. Decomposition during recovery could account for the high oxygen isotope value $(+2.80 \%)$ and low chlorinity $(17.21 \mathrm{~g} / \mathrm{kg})$ observed at this depth. High alkalinity and dissolved ammonia ( $71 \mathrm{meq} / \mathrm{l}$ and $33 \mathrm{mM}$, respectively) indicate substantial microbial activity.

Chlorinity gradually increases with depth in the 1600-m-thick sediment column at Site 534, perhaps due to deepseated alteration-hydration reactions or to the presence of nearby evaporites. $\delta^{18} \mathrm{O}$ and $\delta \mathrm{D}$ decrease with depth and are well correlated, suggesting that a common mechanism is fractionating both.
\end{abstract}

\section{INTRODUCTION}

Site 533 is located in the vicinity of Sites 102,103 , and 104 that were drilled during DSDP Leg 11 on the Blake Outer Ridge. Seismic data obtained in this area suggested the presence of gas hydrates in the sediments (Lancelot and Ewing, 1972; Tucholke et al., 1977; Shipley et al., 1979; Dillon et al., 1980). Site 533 was thus drilled with the specific aim of testing for the presence of gas hydrates in the sediments and to carry out detailed investigations of the inorganic and organic geochemistry of these sediments and their interstitial waters. The sediments cored were middle Pliocene to Holocene gray green muds. Interstitial water was sampled to a sub-bottom depth of $400 \mathrm{~m}$.

Site 534 was drilled in the Blake-Bahama Basin in order to add to information derived from coring at Site 391 (DSDP Leg 44). Interstitial water was continuously sampled from 500 to $1100 \mathrm{~m}$ sub-bottom depth. Sediments in this interval consisted primarily of Lower Cretaceous to Miocene chalk, carbonaceous claystone, and limestone. Because sampling of interstitial water ceased well short of the basement depth of $1635 \mathrm{~m}$, interpretation of the data at Site 534 is somewhat restricted.

In this chapter, we present the data obtained both on board ship and in our home laboratories on the inorganic chemistry of the interstitial waters. Data on the carbon isotopic composition of the dissolved carbon dioxide are presented elsewhere (Claypool, this volume).

\section{METHODS}

Shore-based analyses of dissolved constituents were carried out at Scripps Institution of Oceanography according to methods described by Gieskes (1974). Stable isotope analyses for interstitial water oxygen

\footnotetext{
${ }^{1}$ Sheridan, R. E., Gradstein, F. M., et al., Init. Repts, DSDP, 76: Washington (U.S. Govt. Printing Office).
}

and hydrogen were run at the Institute of Geophysics and Planetary Physics at UCLA. Oxygen was prepared from 1- to 2-ml aliquots by the standard carbon dioxide equilibration method (Epstein and Mayeda, 1953). Appropriate corrections for the isotopic contribution of tank carbon dioxide were made (Craig, 1957). Hydrogen was prepared by passing $5 \mu \mathrm{l}$ aliquots of water through a furnace packed with uranium turnings at $750^{\circ} \mathrm{C}$ (Bigeleisen et al., 1952). Analyses were run on a Varian MAT 250 stable isotope mass spectrometer. Results are expressed in del $(\delta)$ notation relative to the SMOW standard. Standard deviations determined from six replicate runs of laboratory standards are $\pm 0.10 \%$ for $\delta^{18} \mathrm{O}$ and $\pm 1.9 \%$ for $\delta \mathrm{D}$.

\section{RESULTS}

The shipboard data and the results of this study are presented in Table 1.

\section{Site 533}

Gas hydrates were first recovered by DSDP during Legs 66 and 67 in the continental slope sediments of the Mid-America Trench (Shipley and Didyk, 1982; Aubouin, von Huene, et al., 1982). Harrison et al. (1982) and Hesse and Harrison (1981) studied the interstitial water chemistry of the sites drilled during Leg 67 and established substantial decreases in dissolved chloride along with significant increases in $\delta^{18} \mathrm{O}$ with depth at Sites 496 and 497 . These observations were explained in terms of hydrate decomposition during core recovery. Chlorinity decreases and $\delta^{18} \mathrm{O}$ increases would occur as a result of the addition of fresh, $\mathrm{H}_{2}{ }^{18} \mathrm{O}$-enriched water from the hydrates that exclude salt and which, by comparison with ice (O'Neil, 1968; Trofimuk et al., 1974), are assumed to concentrate ${ }^{18} \mathrm{O}$ relative to the water in which they form. The chlorinity decreases at Sites 496 and 497 were fairly uniform (Harrison et al., 1982; Hesse and Harrison, 1981), but at the hydrate-containing sites of Leg 66 , decreases in chlorinity were sporadic and only occurred in hydrate-bearing zones (Gieskes, unpublished data). Similarly, chlorinity decreases were observed at Sites 102 to 104 (Sayles et al., 1972). The 
Table 1. Interstitial water chemistry, Leg 76, Holes 533, 533A, and 534A.

\begin{tabular}{|c|c|c|c|c|c|c|c|c|c|c|c|c|c|c|c|}
\hline $\begin{array}{c}\text { Sample } \\
\text { (interval in } \mathrm{cm} \text { ) }\end{array}$ & $\begin{array}{l}\text { Sub-bottom } \\
\text { depth } \\
\text { (m) }\end{array}$ & $\mathrm{pH}$ & $\begin{array}{c}\text { Alk } \\
(\mathrm{meq} / \mathrm{l})\end{array}$ & $\underset{(g / k g)}{S}$ & $\begin{array}{c}\mathrm{Ca} \\
(\mathrm{mM})\end{array}$ & $\begin{array}{l}\mathrm{Mg} \\
(\mathrm{mM})\end{array}$ & $\underset{(\mathrm{g} / \mathrm{kg})}{\mathrm{Cl}}$ & $\begin{array}{c}\mathrm{Sr} \\
(\mu \mathrm{M})\end{array}$ & $\underset{(\mu \mathrm{M})}{\mathrm{LI}}$ & $\underset{(\mu \mathrm{M})}{\mathrm{K}}$ & $\underset{(\mathrm{mM})}{\mathrm{SO}_{4}}$ & $\begin{array}{l}\mathrm{NH}_{4} \\
(\mu \mathrm{M})\end{array}$ & $\underset{(\mu \mathrm{M})}{\mathrm{Si}}$ & $\begin{array}{c}\delta^{18} \mathrm{O} \\
(\%)\end{array}$ & $\begin{array}{l}\delta \mathrm{D} \\
(\% \mathrm{o})\end{array}$ \\
\hline \multicolumn{16}{|l|}{ Hole 533} \\
\hline $1-1,135-140$ & 1 & 7.39 & 8.49 & 35.04 & 8.67 & 56.7 & 19.31 & 72.2 & 34 & 11.07 & 23.9 & 488 & 422 & -0.14 & -4.9 \\
\hline $2-1,75-80$ & 3 & 7.58 & 11.88 & 34.76 & 7.27 & 47.2 & 19.43 & 57.0 & 31 & 8.85 & 18.8 & 798 & 581 & +0.09 & -3.3 \\
\hline $5-1,140-145$ & 10 & 7.47 & 18.48 & 33.83 & 3.86 & 46.8 & 19.50 & 42.4 & 31 & 11.37 & 9.9 & 1403 & 684 & - & - \\
\hline $6-2,145-150$ & 14 & 7.62 & 24.61 & 33.17 & 2.32 & 43.2 & 19.46 & 44.5 & 20 & 11.21 & - & 1880 & 394 & -0.13 & -1.3 \\
\hline $7-2,145-150$ & 19 & 7.73 & 26.38 & 33.11 & 2.02 & 42.5 & 19.19 & 26.0 & 25 & 11.32 & 1.1 & 2262 & 462 & +0.02 & -2.1 \\
\hline $8-1,140-145$ & 22 & 7.67 & 26.52 & 33.28 & 2.22 & 41.7 & 19.53 & 45.5 & 21 & 11.73 & - & 2355 & 520 & +0.22 & -2.2 \\
\hline $9-2,140-145$ & 28 & 7.59 & 26.69 & 33.22 & 2.01 & 40.8 & 19.53 & 26.0 & 21 & 12.14 & 2.6 & 2892 & 663 & +0.25 & -4.3 \\
\hline $10-2,140-145$ & 32 & 8.13 & 25.55 & 33.22 & 1.37 & 38.6 & 19.53 & 25.6 & 24 & 11.9 & - & 3380 & 371 & -0.02 & +0.3 \\
\hline $11-2,140-145$ & 37 & 7.75 & 27.44 & 33.44 & 2.15 & 38.5 & 19.53 & 45.5 & 29 & 10.83 & 1.1 & 3482 & 611 & +0.48 & -0.5 \\
\hline $12-1,140-145$ & 40 & 7.59 & 25.02 & 33.35 & 1.89 & 39.3 & 19.55 & 25.6 & 28 & 10.74 & - & 39.42 & 576 & +0.27 & -4.4 \\
\hline $13-2,140-150$ & 46 & 7.85 & 25.53 & 33.17 & 1.57 & 37.5 & 19.31 & 25.6 & 29 & 12.76 & 1.3 & 4224 & 384 & -0.60 & -1.8 \\
\hline $14-1,145-150$ & 48 & 7.88 & 24.64 & 33.39 & 2.04 & 36.6 & 19.50 & 44.8 & 29 & 11.5 & - & 4096 & 442 & -0.24 & -3.3 \\
\hline $16-2,145-150$ & 58 & 8.06 & 24.01 & 32.89 & 1.65 & 38.9 & 19.37 & 44.8 & 24 & 13.57 & 1.1 & 5120 & 326 & +0.14 & -3.2 \\
\hline $18-1,140-150$ & 65 & 8.00 & 25.61 & 33.11 & 1.91 & 38.9 & 19.41 & 45.5 & 18 & 10.83 & - & 5200 & 481 & -0.72 & -1.9 \\
\hline $20-2,140-150$ & 76 & 7.81 & 24.93 & 33.28 & 2.15 & 34.4 & 19.34 & 44.8 & 18 & 12.35 & 1.1 & 5427 & 576 & -0.19 & -2.7 \\
\hline $22-1,140-150$ & 83 & 7.83 & 23.02 & 32.78 & 1.74 & 32.3 & 19.24 & 44.8 & 40 & 13.49 & - & 6195 & 512 & +0.18 & -3.2 \\
\hline $24-1,140-150$ & 92 & 7.82 & 23.11 & 32.67 & 1.86 & 29.7 & 19.24 & 44.8 & 40 & 13.17 & 1.1 & 6656 & 570 & +0.17 & $-3: 3$ \\
\hline $26-2,0-10$ & 101 & 7.74 & 22.39 & 32.51 & 1.89 & 27.8 & 18.90 & 41.1 & 28 & 11.77 & 1.1 & 6904 & 435 & -0.21 & -3.7 \\
\hline $28-2,140-150$ & 112 & 7.92 & 23.22 & 32.51 & 2.10 & 24.8 & 18.84 & 63.0 & 39 & 12.16 & 1.1 & 7378 & 271 & +0.35 & -3.5 \\
\hline $30-1,140-150$ & 119 & 7.82 & 25.55 & 32.62 & 2.28 & 25.3 & 18.93 & 64.0 & 45 & 12.20 & 2.9 & 8140 & 570 & -0.19 & -6.6 \\
\hline $32-2,140-150$ & 130 & 7.94 & 25.29 & 32.67 & 1.61 & 22.3 & 18.98 & 44.8 & 50 & 14.78 & 1.1 & 9057 & 518 & -0.29 & -5.1 \\
\hline $34-1,140-150$ & 137 & 7.93 & 27.20 & 32.78 & 1.43 & 22.9 & 18.91 & 57.2 & 56 & 14.11 & 1.2 & 9326 & 488 & -0.19 & - \\
\hline $37-1,140-150$ & 148 & 7.85 & 27.07 & 32.78 & 1.34 & 22.8 & 18.88 & 57.2 & 64 & 13.78 & 1.0 & 9807 & 384 & -0.24 & -4.9 \\
\hline $40-1,140-150$ & 160 & 7.95 & 32.82 & 32.89 & 1.87 & 22.7 & 18.74 & 68.0 & 82 & 8.84 & - & 11,000 & 592 & -0.66 & -3.9 \\
\hline \multicolumn{16}{|l|}{ Hole 533A } \\
\hline $3-2,140-150$ & 155 & 7.54 & 26.79 & 33.83 & 3.76 & 28.7 & 19.21 & 84.5 & 92 & 11.4 & $<2$ & 7384 & 813 & -0.31 & -6.0 \\
\hline $4-2,140-150$ & 157 & 7.57 & 35.24 & 33.72 & 3.69 & 28.4 & 19.07 & 68.0 & 106 & 10.1 & - & 8812 & 666 & -0.02 & -7.4 \\
\hline $8-2,140-150$ & 193 & 7.45 & 68.63 & 34.10 & 3.98 & 27.5 & 18.70 & 60.2 & 189 & 14.5 & $<2$ & 16,600 & 1041 & -0.45 & -9.2 \\
\hline $10-6,5-15$ & 216 & 7.25 & 70.86 & 34.43 & 5.06 & 27.9 & 18.65 & 87.0 & 209 & 14.9 & $<2$ & 16,000 & 922 & -1.03 & -16.5 \\
\hline $13-4,135-150$ & 243 & 7.54 & 48.34 & 33.73 & 4.26 & 24.6 & 18.07 & 121.6 & 302 & 15.9 & - & 19,900 & 1352 & -1.88 & -18.9 \\
\hline $15-1,140-150$ & 258 & 7.55 & 40.77 & 32.40 & 4.53 & 25.0 & 17.95 & 72.0 & 183 & 13.0 & $<2$ & 15,500 & 655 & +0.23 & -6.5 \\
\hline $16-4,135-145$ & 272 & 7.20 & 56.00 & 34.38 & 4.79 & 24.6 & 18.49 & 56.0 & - & 9.9 & - & 14,900 & 848 & -0.55 & -12.8 \\
\hline $18-6,140-150$ & 294 & 7.55 & 48.16 & 31.57 & 3.21 & 19.2 & 17.21 & 53.2 & 219 & 10.7 & $<2$ & 8876 & 707 & +2.80 & 0.0 \\
\hline $20-2,140-150$ & 307 & 7.45 & 53.70 & 33.83 & 4.74 & 22.1 & 18.34 & 54.6 & 270 & 12.9 & - & 19,200 & 702 & -0.54 & -10.0 \\
\hline $22-6,135-145$ & 332 & 7.63 & 42.40 & 32.29 & 3.43 & 21.1 & 17.66 & 73.0 & 266 & 11.8 & $<2$ & 16,800 & 752 & -0.26 & -10.3 \\
\hline $24-5,140-150$ & 349 & 7.51 & 48.23 & 33.11 & 3.79 & 19.9 & 17.93 & 99.0 & 471 & 18.8 & - & 33,200 & 1117 & +0.06 & -10.7 \\
\hline $26-3,140-150$ & 365 & 7.49 & 49.08 & 33.22 & 3.97 & 20.5 & 18.34 & 99.0 & 506 & 19.9 & $<2$ & 29,600 & 1125 & - & - \\
\hline $29-3,140-150$ & 396 & 7.24 & 41.03 & 33.33 & 5.09 & 22.1 & 18.37 & 93.6 & 263 & 12.5 & $<2$ & 21,300 & 706 & +0.06 & -9.5 \\
\hline \multicolumn{16}{|l|}{ Hole 534A } \\
\hline $3-2,135-145$ & 558 & 7.15 & 8.81 & 34.27 & 15.2 & 34.6 & 20.7 & 1919 & - & 9.10 & 7.3 & 1836 & 840 & -1.80 & -9.4 \\
\hline $7-2,140-150$ & 596 & 7.02 & 8.11 & 34.87 & 17.5 & 34.3 & 20.11 & 1866 & - & 8.7 & 6.3 & 2156 & 941 & -2.20 & -11.9 \\
\hline $10-3,105-120$ & 617 & 7.01 & 8.91 & 34.49 & 18.9 & 32.6 & 20.31 & 1737 & - & 8.3 & 6.3 & 2150 & 846 & -2.20 & -11.7 \\
\hline $14-2,135-150$ & 653 & 7.08 & 7.35 & 34.38 & 20.6 & 33.1 & 20.4 & 1606 & - & 3.3 & - & 1650 & 847 & -1.82 & -11.5 \\
\hline $20-2,135-150$ & 708 & 7.27 & 3.94 & 34.43 & 25.4 & 34.4 & 20.20 & 968 & - & 4.9 & 6.7 & 1236 & 834 & -2.32 & -12.0 \\
\hline $24-2,135-150$ & 744 & 7.47 & 3.25 & 33.55 & 28.3 & 34.0 & 19.42 & 932 & - & 3.5 & - & 541 & 273 & -2.41 & -12.9 \\
\hline $27-1,140-150$ & 766 & 8.23 & 2.10 & 32.62 & 26.8 & 31.4 & 18.83 & 1102 & - & 3.6 & 8.5 & 707 & 73 & -2.39 & -11.4 \\
\hline $29-2,135-150$ & 786 & 8.24 & 2.60 & 35.31 & 29.1 & 35.2 & 20.19 & 1217 & - & 5.1 & - & 790 & 78 & -1.98 & -8.7 \\
\hline $32-1,132-150$ & 813 & 7.61 & 2.29 & 36.30 & 31.2 & 38.6 & 20.53 & 1238 & - & 3.1 & 15.5 & 624 & 130 & -1.52 & -6.6 \\
\hline $34-1,105-120$ & 832 & 8.10 & 2.30 & 33.80 & 31.5 & 33.2 & 19.62 & 1300 & - & 3.7 & - & 478 & 78 & -2.67 & -16.4 \\
\hline $36-2,135-150$ & 853 & 8.05 & 2.19 & 35.83 & 33.5 & 34.4 & 20.91 & 1388 & - & 2.8 & 6.8 & 540 & 88 & -2.83 & -14.5 \\
\hline $38-4,135-150$ & 875 & 8.09 & 1.77 & 36.71 & 34.1 & 38.1 & 20.57 & 1414 & - & 3.9 & 14.6 & 478 & 78 & -1.85 & -7.1 \\
\hline $41-4,135-150$ & 902 & 8.42 & 1.25 & 34.21 & 34.9 & 35.0 & 19.67 & 1581 & - & 3.2 & 9.4 & 478 & 88 & -3.87 & -13.6 \\
\hline $43-1,135-150$ & 915 & 7.70 & 0.94 & 37.02 & 36.6 & 36.6 & 21.29 & 1581 & - & 4.1 & 10.2 & 499 & 109 & -2.83 & -13.8 \\
\hline $45-2,135-150$ & 935 & 7.47 & 0.77 & 37.02 & 36.7 & 36.2 & 21.49 & 1501 & - & 3.5 & - & - & 102 & -2.86 & -12.8 \\
\hline $49-2,140-150$ & 966 & - & - & 37.51 & 39.5 & 37.1 & 21.69 & - & - & - & - & - & - & -3.01 & -15.5 \\
\hline $52-1,0-15$ & 990 & 7.43 & 0.33 & 37.51 & 43.6 & 36.5 & 21.56 & 1918 & - & 3.9 & 7.6 & 489 & 71 & -2.84 & -17.4 \\
\hline $56-1,140-150$ & 1028 & - & - & 37.51 & 47.6 & 37.0 & 21.61 & - & - & - & - & - & - & -2.10 & -10.3 \\
\hline $58-2,135-150$ & 1047 & - & - & 37.45 & 56.3 & 36.5 & 21.87 & 1890 & - & 2.4 & - & 520 & 75 & - & -12.7 \\
\hline $61-2,127-142$ & 1074 & - & - & 39.22 & 63.1 & 35.3 & 22.37 & 2510 & - & 2.8 & - & 500 & 80 & -2.80 & -14.6 \\
\hline $63-2,105-120$ & 1092 & - & - & 39.33 & 63.8 & 36.0 & 22.37 & - & - & - & - & - & - & -5.78 & -14.1 \\
\hline $64-4,135-150$ & 1104 & - & - & 39.33 & 64.4 & 35.1 & 21.86 & 1970 & - & 1.3 & 8.2 & 520 & 80 & -2.53 & -15.4 \\
\hline $94-3,0-15$ & 1357 & - & - & - & - & - & - & - & - & - & - & - & - & -2.97 & -15.1 \\
\hline $100-3,135-150$ & 1405 & - & - & - & - & - & - & - & - & - & - & - & - & -3.43 & -17.0 \\
\hline
\end{tabular}

Note: - indicates no data available. 
concentration-depth profiles of chloride in these sites are presented in Figure 1. Lancelot and Ewing (1972) suggest that gas hydrates on the Blake Outer Ridge may decompose below a sub-bottom depth of $\sim 600 \mathrm{~m}$, that is, below the bottom simulating reflector (BSR). The chlorinity data suggest that this depth horizon may, in fact, be located somewhat deeper at this site.

Figures 2 and 3 illustrate the shipboard and shorebased data for dissolved species at Site 533. Again, a gradual decrease in chlorinity is observed in Hole 533 (Fig. 2), whereas the deeper horizons cored in Hole 533A (Fig. 3) show a rather complex pattern in chlorinity. The latter pattern is mimicked to a certain extent by the concentration depth profiles of dissolved ammonia, magnesium, lithium, and perhaps potassium. Whether these jagged profiles are the result of dilution caused by hydrate decomposition cannot be fully ascertained, but data for dissolved constituents of the intersitial fluids suggest that this is indeed the case.

Sulfate depletion is essentially complete below $20 \mathrm{~m}$ (Fig. 2), and ammonia concentrations gradually increase with depth to concentrations as high as $30 \mathrm{mM}$ at $\sim 400$ $\mathrm{m}$ sub-bottom. Such observations are typical at sites where extensive methane production occurs (Gieskes et al., 1982; Harrison et al., 1982). Dissolved calcium remains low throughout the drilled section of Site 533. Dissolved magnesium decreases with depth, but it is difficult to pinpoint reactions responsible for these decreases. The data on dissolved strontium are puzzling. They appear too low and scattered, and we suspect that the data are not reliable. To some extent, this statement also applies to the data on dissolved potassium.

Figure 4 shows the depth profiles of $\delta^{18} \mathrm{O}$ and $\delta \mathrm{D}$ for Site 533 (Holes 533 and 533A combined). Large fluctuations in the depth ranging from 160 to $360 \mathrm{~m}$ sub-bottom add further support to the hypothesis of hydrate decomposition during core recovery. Section 533A-18-6 $(294 \mathrm{~m})$ shows both the lowest observed chlorinity

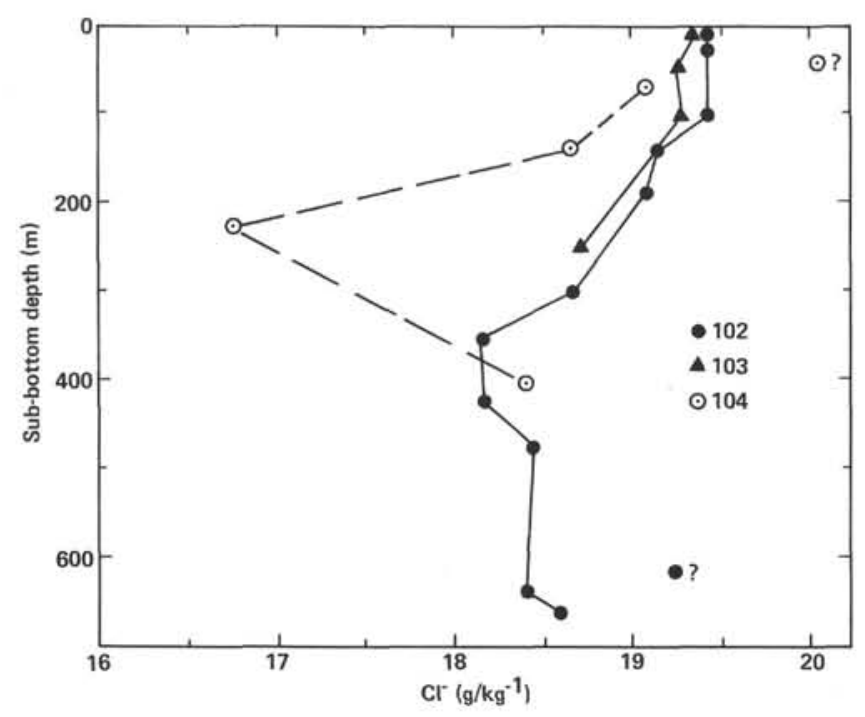

Figure 1. Chlorinity data for Sites 102, 103, and 104, DSDP Leg 11 (Sayles et al., 1972).
$(17.21 \mathrm{~g} / \mathrm{kg})$ and the highest observed isotopic composition $\left(+2.80 \%\right.$ and $+0.0 \%$ for $\delta^{18} \mathrm{O}$ and $\delta \mathrm{D}$, respectively). As Hesse and Harrison (1981) have noted, it is difficult to explain positive oxygen isotope compositions of such a magnitude by a mechanism other than hydrate decomposition. Figure 5 presents a simple model illustrating the effect of an isolated gas-hydrate layer on the local pore water chemistry from the time of hydrate crystallization to the time of decomposition during coring operations. Assuming that solutes move by diffusion only and that the hydrate concentrates the heavier isotopes, we expect to observe low chlorinities and high $\delta^{18} \mathrm{O}$ and $\delta \mathrm{D}$ marking the horizon where the hydrate existed. Moreover, we would expect to see diffusion-related deflections above and below the hydrate layer with high chlorinities and low $\delta^{18} \mathrm{O}$ and $\delta \mathrm{D}$. Just this pattern of behavior is observed between 260 and $320 \mathrm{~m}$ when chlorinity and $\delta^{18} \mathrm{O}$ are plotted side by side in Figure 6 . A hydrate-bearing region may, therefore, have existed around $290 \mathrm{~m}$ sub-bottom prior to coring operations. Hydrate may also have been present at $\sim 260 \mathrm{~m}$ sub-bottom. It is interesting to note, however, that although a small piece of hydrate was recovered at $243 \mathrm{~m}$ sub-bottom, no chlorinity and isotope "fingerprint" was observed. The lack of a fingerpoint may indicate that the hydrate bed cored was small and isolated. The lack of recovery at $290 \mathrm{~m}$ sub-bottom, on the other hand, suggests that whereas the total amount of hydrate present was substantial $(10 \%$ of the pore space by shipboard estimation), the hydrate probably existed in very thin, diffuse layers that decomposed quickly.

It is clear that this interpretation does not explain all the fluctuations in Figure 6. From 160 to $240 \mathrm{~m}$ sub-bottom, chlorinity and $\delta^{18} \mathrm{O}$ both decrease, showing a positive rather than a negative correlation. Indeed, a plot of $\delta \mathrm{D}$ against chlorinity for Site 533 also shows a weak but positive correlation that would not be expected for hydrate formation or decomposition (Fig. 7). One possible explanation is an infiltration of low-chlorinity, isotopically light water from elsewhere. Gieskes (1981) cited an example of fresh water imprints on hemipalagic sediments as far as $\mathbf{2 0 0} \mathrm{mi}$. from land. Such an hypothesis at Site 533 seems extremely unlikely, however, in view of the lack of sandy beds that could act as aquifers and the distance of this site from the mainland $(\sim 300$ mi.). Other explanations are not readily apparent.

\section{Site 534}

Figure 8 presents concentration depth profiles of shipboard and shore-based data for dissolved species at Site 534. Data for alkalinity, calcium, and magnesium indicate that Site 534 is a representative continuation of Site 391 . Below $500 \mathrm{~m}$, little change occurs in dissolved magnesium, but dissolved calcium increases gradually with depth, indicating a source in the deeper sections.

Dissolved silica data indicate a sharp decrease below $750 \mathrm{~m}$, that is, below Unit IV. Concentrations in Unit V (carbonaceous claystones) are very low. The boundary between Units IV and V (Fig. 8) is also marked by a minimum in dissolved strontium. Presumably, strontium is produced by recrystallization of carbonates in the 

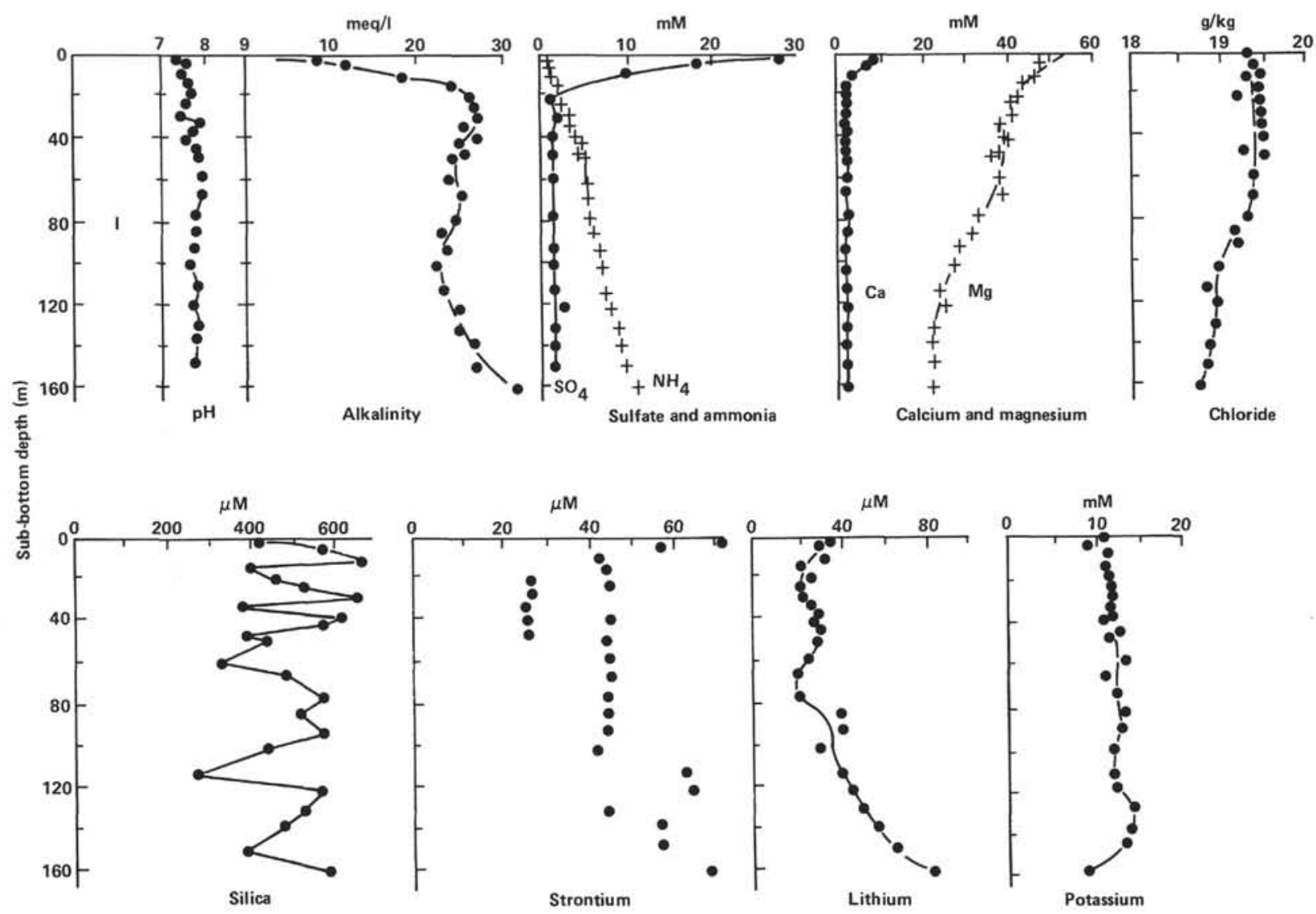

Figure 2. Interstitial water chemistry, Hole 533. (Lithology: Unit I-nannofossil marl and silty nannofossil clays [Holocene-Pleistocene].)

chalks above $500 \mathrm{~m}$, and in the limestones of Unit VI (Fig. 8). Alkalinity values decrease rapidly below $700 \mathrm{~m}$, probably as a result of reactions taking place in Unit V. Dissolved potassium clearly indicates a sink for this element in the claystone of Unit V.

Of interest is the gradual increase in dissolved chloride with depth (Fig. 8). Superimposed on this are very sharp decreases in Unit V. Data on dissolved calcium and magnesium do not suggest that these results are due to seawater contamination. Another possibility is that slight contamination may have occurred because of inadequate drying of the squeezing apparatus. Of some interest, however, is the shipboard observation that zones of low porosity in Unit V correspond to the low chlorinity values. At this stage it is not clear what may have caused the chlorinity anomalies. There is little doubt, however, that chloride concentrations do increase with depth, perhaps related to alteration and/or hydration reactions taking place in deeper, unsampled sediment sections or to the presence of nearby evaporites.

Interstitial water oxygen and hydrogen isotope depth profiles for Site 534 are shown in Figure 9. Except for sharp negative deflections in $\delta^{18} \mathrm{O}$ at $900 \mathrm{~m}$ and $1090 \mathrm{~m}$ sub-bottom depth, the two profiles match closely. Both show slight decreases with depth, $-1.6 \%$ and about $-7 \%_{0} / \mathrm{km}$ for $\delta \mathrm{D}$. The strong fluctuations between 750 and $950 \mathrm{~m}$ sub-bottom (carbonaceous claystone unit) appear to mimic variations in chlorinity and sediment porosity in the same interval and may be re- lated to them. The sharp negative deflection in $\delta^{18} \mathrm{O}$ observed at $1090 \mathrm{~m}(534 \mathrm{~A}-63-2,-5.78 \%$ ) does not correlate with $\delta \mathrm{D}$ or chlorinity. Calcium, however, shows a steep gradient between 950 and $1050 \mathrm{~m}$ sub-bottom, which may indicate a source near $1100 \mathrm{~m}$. Strontium shows a local maximum here and potassium has a sink near (or perhaps below) $1100 \mathrm{~m}$. Taken together, these observations suggest that some sort of sediment alteration may be occurring around $1090 \mathrm{~m}$ that escaped shipboard notice.

As has been noted in the previous discussion, oxygen and hydrogen isotopic compositions generally vary together at Sites 533 and 534 . A plot of $\delta \mathrm{D}$ against $\delta^{18} \mathrm{O}$ illustrates this more clearly (Fig. 10). Deeper, older sediments are generally more depleted in interstitial water ${ }^{18} \mathrm{O}$ and D. A least-squares fit of the data from Hole 534A gives the relation:

$$
\delta \mathrm{D}=4.2 \delta^{18} \mathrm{O}-2.3
$$

with a correlation coefficient of 0.78 . Although the coefficient is not very high, the linear model actually fits quite well, because the residual variance of $\delta \mathrm{D}$ values about the regression line is fully accounted for by the analytical precision of measurement. Section 534A$63-2\left(\delta^{18} \mathrm{O}=-5.78 \%\right)$ was not used to calculate the line, because it lies far from the main cluster of points and may be unreliable. The regression line passes quite close to SMOW standard values and, in fact, fits isotope data from the upper (nonhydrate-bearing) sediments of 

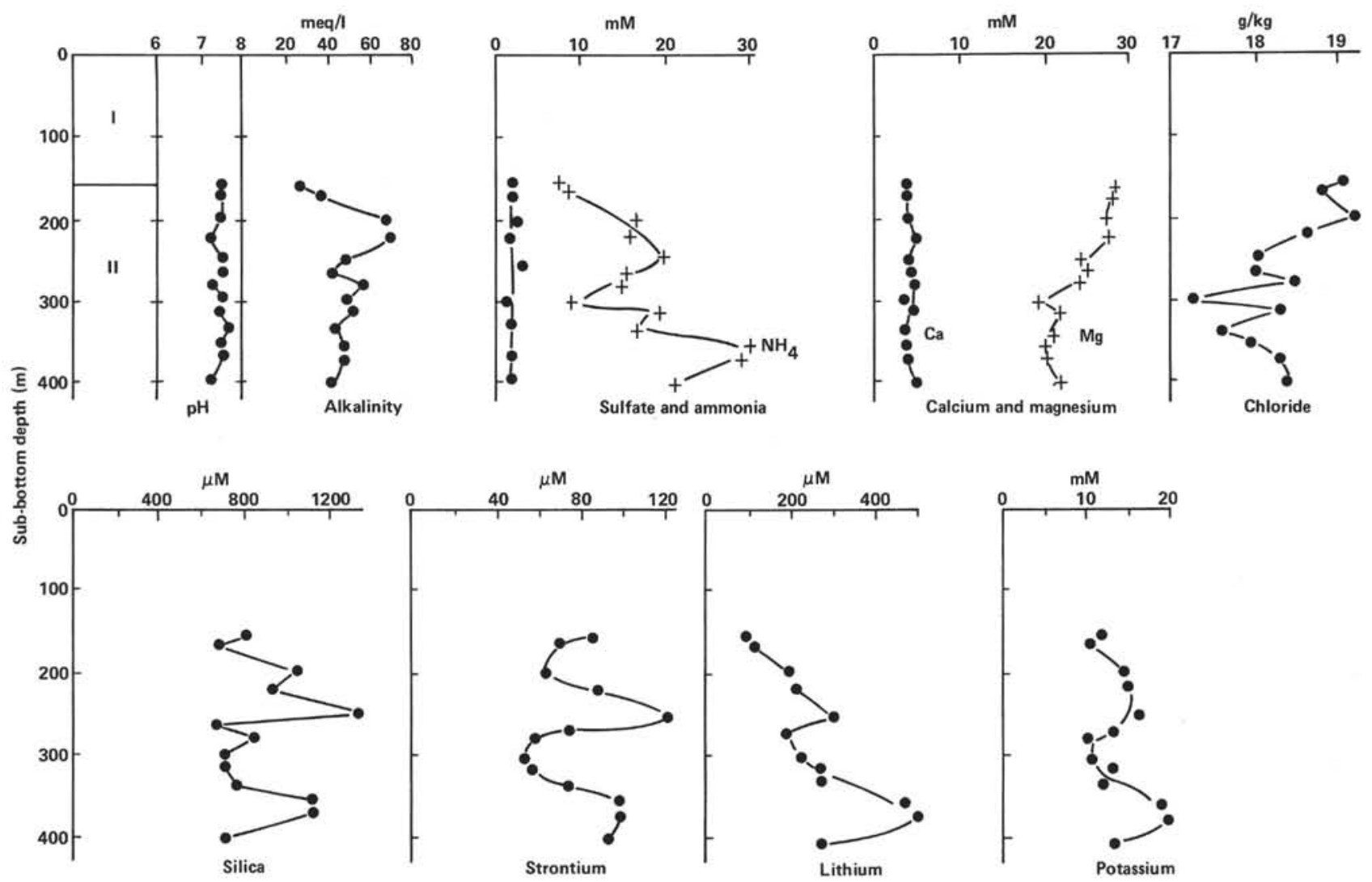

Figure 3. Interstitial water chemistry, Hole 533A. (Lithology: Unit I-nannofossil marl and silty nannofossil clays [Holocene-Pleistocene]; Unit II-medium to dark greenish gray silty nannofossil clays [middle to late Pliocene]).
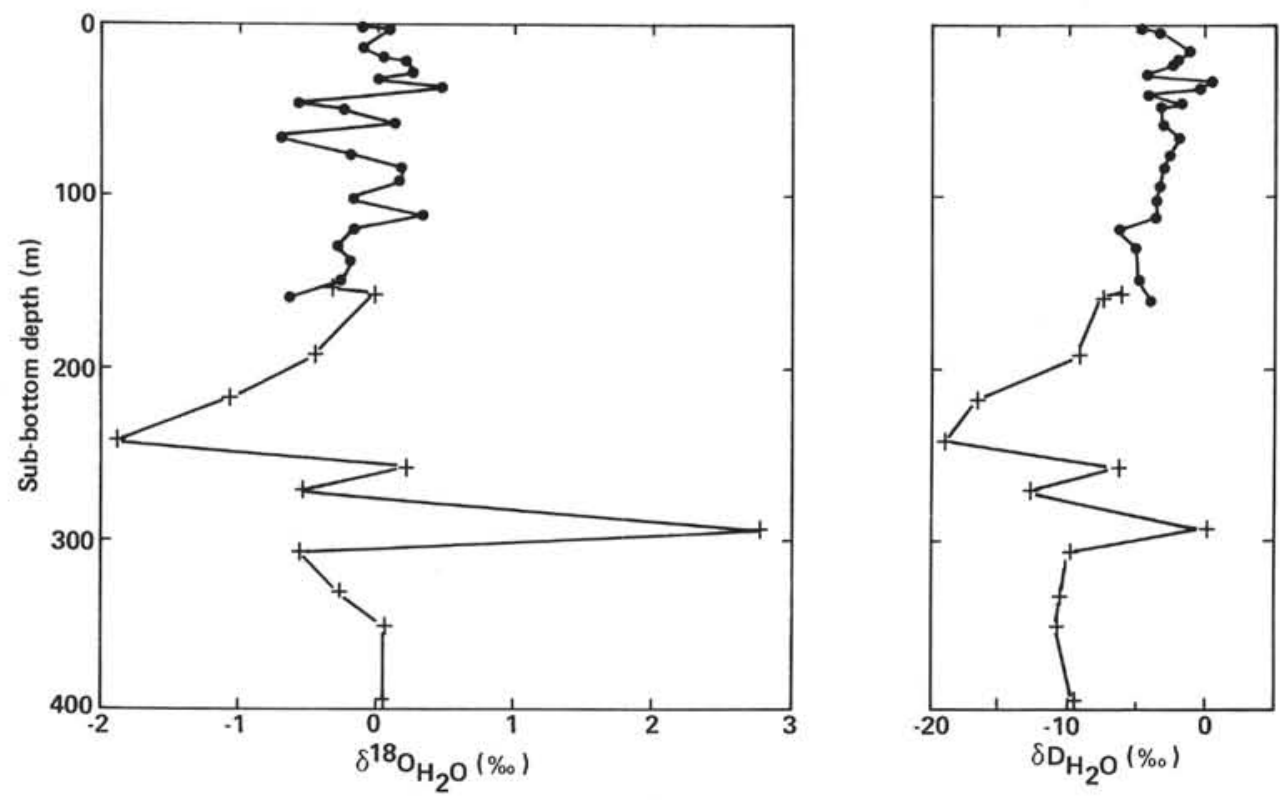

Figure 4. Oxygen and hydrogen stable isotopic composition of interstitial water from Site $533(\bullet=$ Hole 533 ; $+=$ Hole 533A).

Hole 533 reasonably well. For reasons that are not clear (perhaps related to the presence of gas hydrate), the data from Hole 533A all fall below the line, toward higher $\delta^{18} \mathrm{O}$ or lower $\delta \mathrm{D}$ values. A weaker but similar correlation was observed by Lawrence and Gieskes
(1981) when they plotted all the available $\delta^{18} \mathrm{O}$ and $\delta \mathrm{D}$ measurements for interstitial waters at previous DSDP sites.

The reasons for the depth-related depletions in interstitial water deuterium and ${ }^{18} \mathrm{O}$ at Site 534 are difficult 


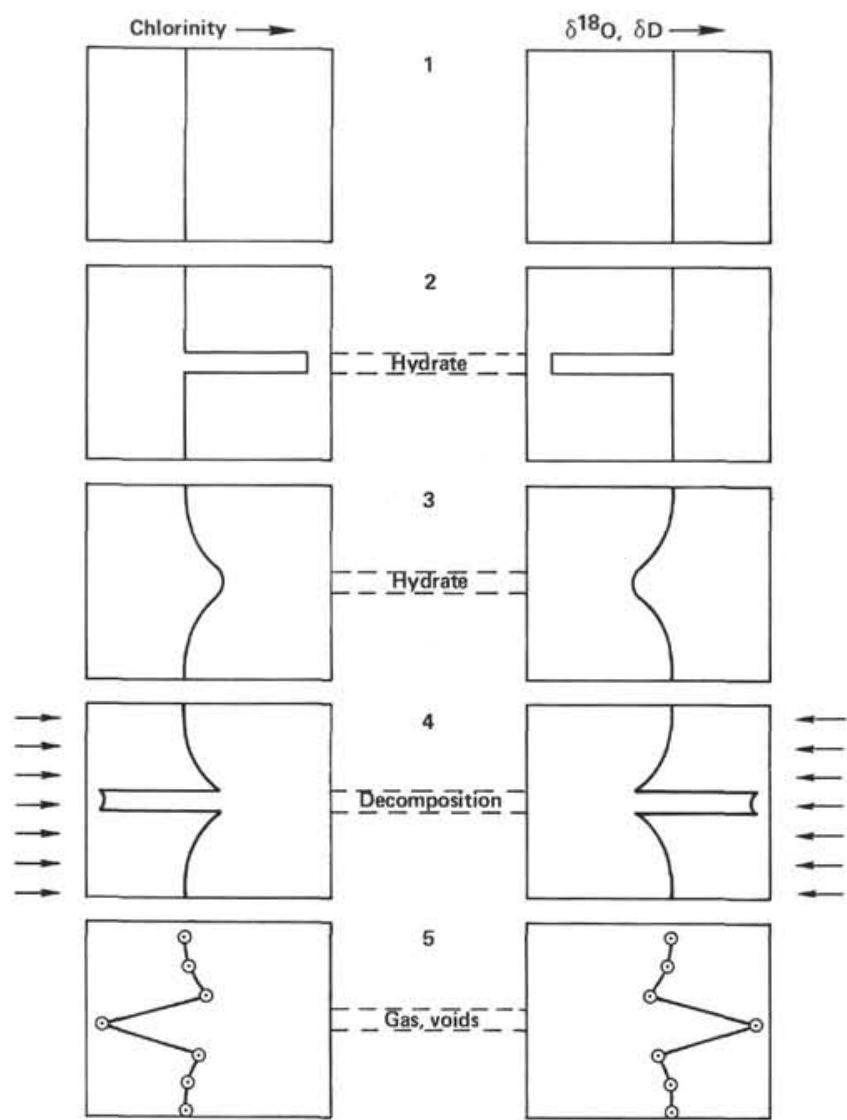

Figure 5. Model for the influence of a hypothetical, isolated gas-hydrate bed on the chlorinity and isotopic composition of surrounding interstitial water. (Frames 1-5 depict chlorinity and isotope composition profiles in the same sedimentary interval from the time of hydrate crystallization to the time of hydrate decomposition during core recovery. 1 . Before hydrate crystallization; 2 . immediately after rapid hydrate crystallization; 3 . just before drilling [the profiles in 3 assume that interstitial water species move predominately by diffusion]; 4 . after complete hydrate decomposition during coring operations [the arrows show the locations of shipboard sampling for interstitial water]; 5 . shipboard reconstruction of chlorinity and isotope composition profiles.)

to identify. Fractionation of the interstitial water isotopes could conceivably have occurred during shipboard squeezing, because unusually high pressures were required to recover samples from the deeper cores (Coplen and Hanshaw, 1973). Further research could readily evaluate this hypothesis. In the case that the observed isotopic trends are not a squeezing artifact, several explanations are possible.

In pelagic sediments, decreases in $\delta^{18} \mathrm{O}$ are usually accompanied by enrichments in dissolved calcium (Lawrence and Gieskes, 1981; Gieskes, 1981). This is attributed to the alteration of volcanic ash and basalt to smectite and other phases (Lawrence et al., 1975; Perry et al., 1976; Lawrence and Gieskes, 1981). The decrease in $\delta \mathrm{D}$ expected for this reaction is minimal, however (Lawrence and Gieskes, 1981), and cannot account for the $\sim 18 \%$ deuterium depletion observed at this site. The possibility also exists that the isotope profiles reflect, in part, a change in the isotopic composition of

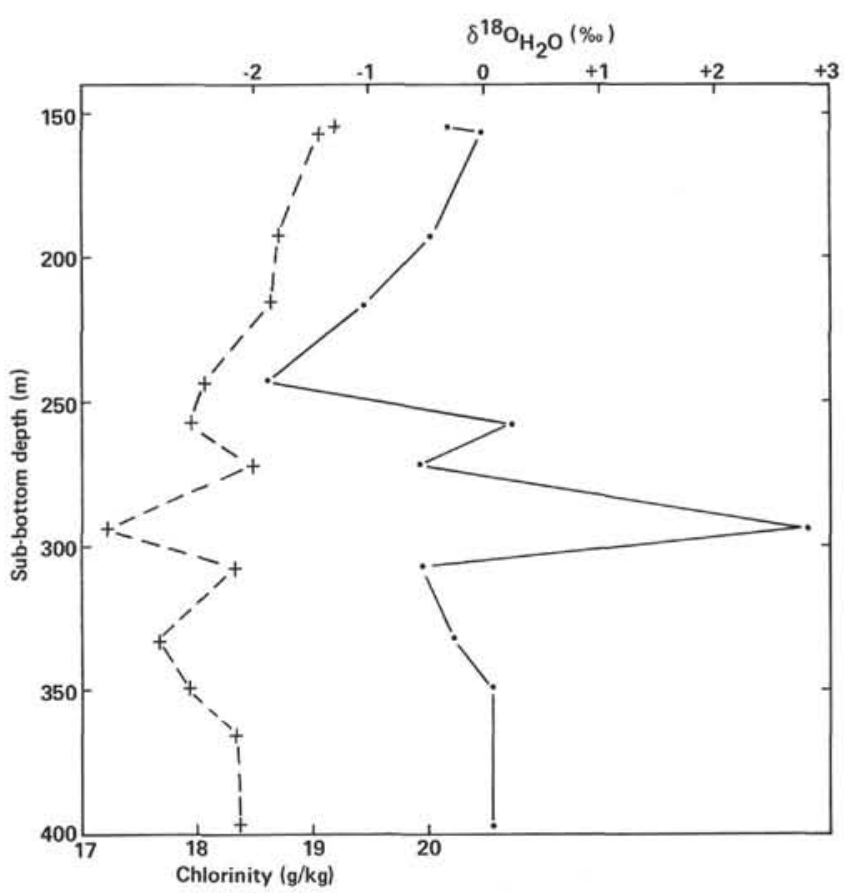

Figure 6. Expanded profiles of chlorinity (dashed line) and $\delta^{18} \mathrm{O}$ (solid line) in interstitial waters from Hole 533A.

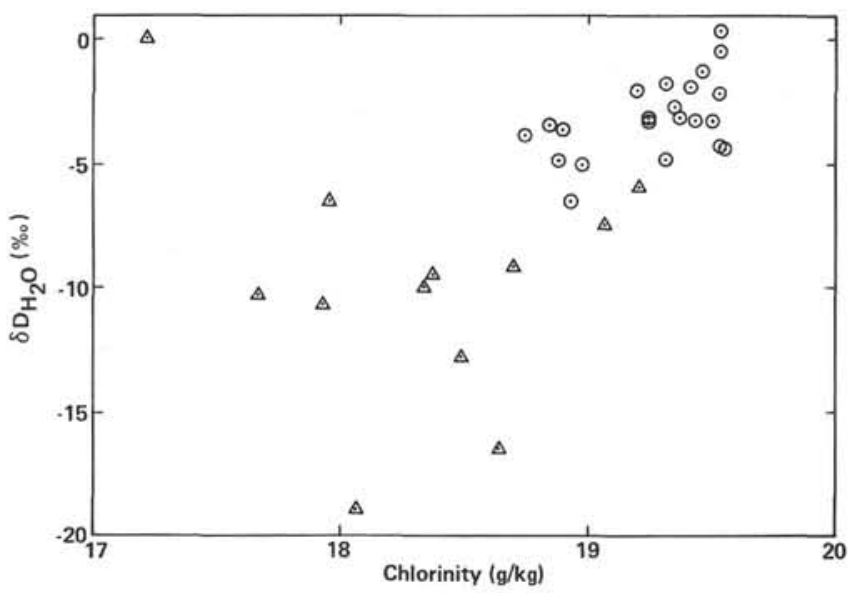

Figure 7. Plot of $\delta \mathrm{D}$ against chlorinity for interstitial waters from Site $533(\odot=$ Hole 533, $\triangle=$ Hole 533A).

the ocean. Some uncertainty exists regarding the isotopic composition of seawater in the geologic past. A strong case has, however, been made for the buffering of the seawater oxygen isotope ratio to within $1 \%$ of its present value (Muehlenbachs and Clayton, 1976; Gregory and Taylor, 1981). According to this model, the ocean is buffered by interaction with new crust generated at mid-ocean spreading centers. This would impose serious constraints on any hypothesis requiring significant variations in $\delta^{18} \mathrm{O}$ of paleo-ocean water through time. Lawrence and Gieskes (1981) proposed that substantial alteration of basalts is occurring in crustal layer II in the presence of low $\delta \mathrm{D}$ paleo-ocean water. This scenario would provide ${ }^{18} \mathrm{O}$ - and $\mathrm{D}$-depleted waters that 


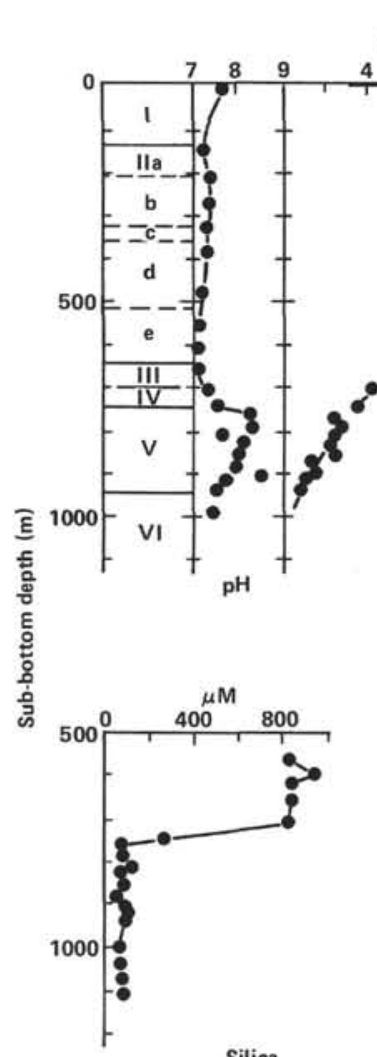

Silica $\mathrm{meq} / \mathrm{l}$

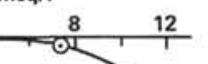

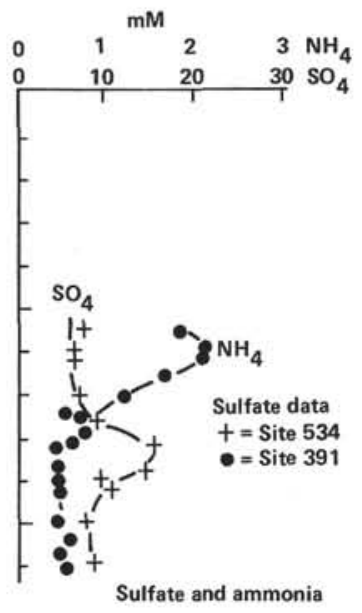

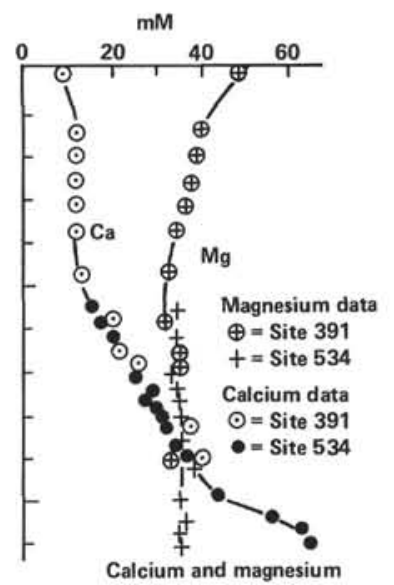

Figure 8. Interstitial water chemistry, Site $391(\mathrm{O})$ and Site 534 (•) (except where otherwise indicated). (Lithology units: I-silty clay, some nannofossil-foraminifer ooze [Quaternary]; IIa-calcareous silt [upper Miocene]; IIb-chalk, clayclast, and marls [middle Miocene]; IIc-radiolarian mudstone [middle Miocene]; IId-intraclastic chalk limestone [middle-lower Miocene]; IIe-mudstones alternating with chalk [lower Miocene]; III-chalk-mudstone [lower Miocene]; IV-zeolitic mudstone, sandstone, porcellanite [upper Eocene]; V-black green carbonaceous claystone [Maestrichtian-Aptian]; and VI-calcareous claystone, chalk [Barremian-Hauterivian].)
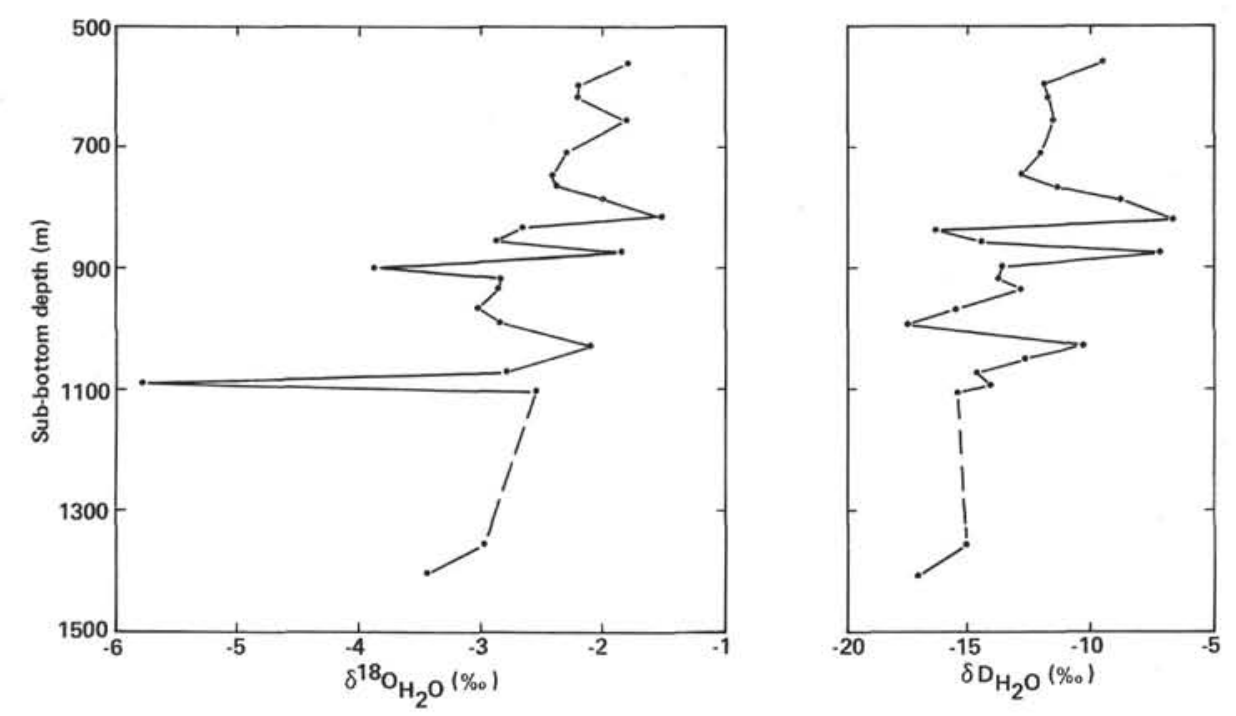

Figure 9. Oxygen and hydrogen stable isotopic composition of interstitial water from Site 534 .

could diffuse into the overlying layer I sediments, thereby causing the observed trends. Whether this mechanism could create an isotopic gradient throughout the $1600 \mathrm{~m}$ of sediment present at Site 534 is doubtful. It is clear that the reason(s) for the depletions in interstitial water $\delta \mathrm{D}$ and $\delta^{18} \mathrm{O}$ at Site 534 are not presently understood. The results of this study do, however, appear to impose one constraint. The observed correlation between $\delta \mathrm{D}$ and $\delta^{18} \mathrm{O}$ suggests that a common mechanism is responsible for both depletions. 


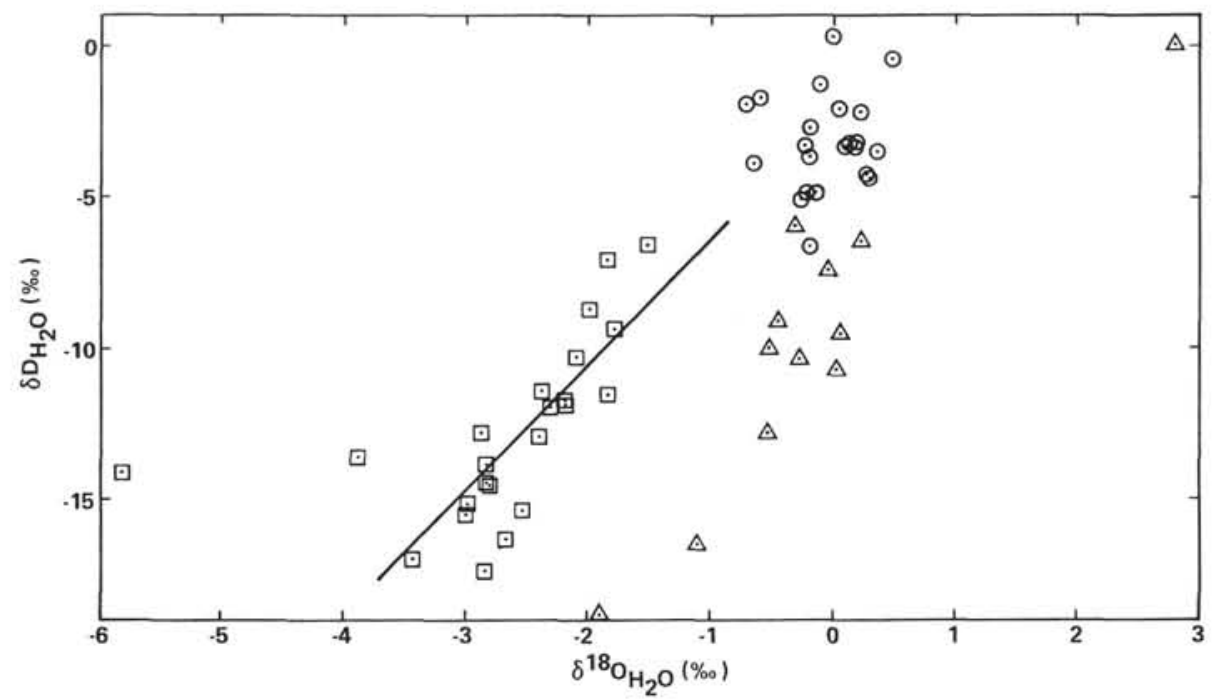

Figure 10. Plot of $\delta \mathrm{D}$ against $\delta^{18} \mathrm{O}$ for interstitial waters from Holes $533(\odot), 533 \mathrm{~A}(\Delta)$, and Hole $534 \mathrm{~A}$

(๑). (See text for the discussion of the regression line.)

\section{CONCLUSIONS}

The principal observations at Site 533 are low salinities together with strong fluctuations in chlorinity, $\delta^{18} \mathrm{O}$, and $\delta \mathrm{D}$ in the main zone of biogenic methane formation. This behavior can be understood, at least in part, in terms of hydrate decomposition during core retrieval. Poor hydrate recovery and the sharp and jagged nature of the chlorinity and isotope profiles indicate that the hydrate probably exists only in thin, diffuse layers that decompose quickly during coring operations.

Of great interest at Site $\mathbf{5 3 4}$ is the gradual increase in chlorinity and decrease in $\delta^{18} \mathrm{O}$ and $\delta \mathrm{D}$ with depth. The increases in dissolved chloride may be related to alteration and/or hydration reactions taking place in the deeper unsampled sections or perhaps to the presence of nearby evaporites. Good correlation between $\delta^{18} \mathrm{O}$ and $\delta \mathrm{D}$ values in this core indicates the same mechanism is probably responsible for depletions in both ${ }^{18} \mathrm{O}$ and $\mathrm{D}$.

\section{ACKNOWLEDGMENTS}

Financial support for this work was generously provided by $\mathrm{Na}$ tional Aeronautics and Space Administration (Grant No. NGR 05-007-221, UCLA) and by the National Science Foundation (Grant No. OCE-80-23966, Scripps Institution of Oceanography). K. Johnston ran shore-based analyses of dissolved constituents, and D. Winter ran the stable isotope mass spectrometer. We are especially grateful to J. R. Lawrence, I. R. Kaplan, R. Hesse, and B. L. Barraclough, who provided helpful discussions and criticisms. This is Contribution No. 2386 of Institute of Geophysics and Planetary Physics, University of California at Los Angeles, Los Angeles, California.

\section{REFERENCES}

Aubouin, J., von Huene, R., et al., 1982. Init. Repts. DSDP, 67: Washington (U.S. Govt. Printing Office).

Bigeleisen, J., Perlman, M. L., and Prosser, H. C., 1952. Conversion of hydrogenic materials to hydrogen for isotopic analysis. Anal. Chem., 24:1356-1357.

Coplen, T. B., and Hanshaw, B. B., 1973. Ultrafiltration by a compacted clay membrane, I. Oxygen and hydrogen isotopic fractionation. Geochim. Cosmochim. Acta, 37:2295-2310.

Craig, H., 1957. Isotopic standards for carbon and oxygen and correction factors for mass-spectrometric analysis of carbon dioxide. Geochim. Cosmochim. Acta, 12:133-149.
Dillon, W. P., Grow, J. A., and Paull, C. K., 1980. Unconventional gas hydrate seals may trap gas off Southwest U.S. Oil Gas J., Jan. 7:124-130.

Epstein, S., and Mayeda, T., 1953. Variation of $\mathrm{O}^{18}$ content of waters from natural sources. Geochim. Cosmochim. Acta, 4:213-224.

Gieskes, J. M., 1974. Interstitial water studies, Leg 25. In Simpson, E. S. W., Schlich, R., et al., Init. Repts. DSDP, 25: Washington (U.S. Govt. Printing Office), 361-394.

1981. Deep-sea drilling interstitial water studies: implications for chemical alteration of the oceanic crust, layers I and II. Soc. Econ. Paleontol. Mineral. Spec. Publ., 32:149-167.

Gieskes, J. M., Elderfield, H., Lawrence, J. R., Johnson, J., Meyers, B., et al., 1982. Geochemistry of interstitial waters and sediments, Leg 64, Gulf of California. In Curray, J. R., Moore, D. G., et al., Init. Repts. DSDP, 64, Pt. 2: Washington (U.S. Govt. Printing Office), 675-694.

Gregory, R. T., and Taylor, H. P., Jr., 1981. An oxygen isotope profile in a section of Cretaceous oceanic crust, Samail Ophiolite, Oman: evidence for $\delta^{18} \mathrm{O}$ buffering of the oceans by deep ( $>5 \mathrm{~km}$ ) seawater-hydrothermal circulation at mid-ocean ridges. J. Geophys. Res., 86:2737-2755.

Harrison, W. E., Hesse, R., and Gieskes, J. M., 1982. Relationship between sedimentary facies and interstitial water chemistry of slope, trench, and Cocos-Plate sites from the Mid-America Trench transect, active margin off Guatemala. In Aubouin, J., von Huene, R., et al., Init. Repts. DSDP, 67: Washington (U.S. Govt. Printing Office), 603-616.

Hesse, R., and Harrison, W. E., 1981. Gas hydrates (clathrates) causing pore water freshening and oxygen isotope fractionation in deep-water sedimentary sections of terrigenous continental margins. Earth Planet. Sci. Lett., 55:453-462.

Lancelot, Y., and Ewing, J., 1972. Correlations of natural gas zonation and carbonate diagenesis in Tertiary sediments from the northwest Atlantic. In Hollister, C. D., Ewing, J. I., et al., Init. Repts. DSDP, 11: Washington (U.S. Govt. Printing Office), 791-799.

Lawrence, J. R., and Gieskes, J. M., 1981. Constraints on water transport and alteration in the oceanic crust from the isotopic composition of pore water. J. Geophys. Res., 86:7924-7934.

Lawrence, J. R., Gieskes, J. M., and Broecker, W. S., 1975. Oxygen isotope and cation composition of DSDP pore waters and the alteration of layer II basalts. Earth Planet. Sci. Lett., 27:1-10.

Muehlenbachs, K., and Clayton, R. N., 1976. Oxygen isotope composition of the oceanic crust and its bearing on seawater. J. Geophys. Res., 81:4365-4369.

O'Neil, J. R., 1968. Hydrogen and oxygen isotope fractionation between ice and water. J. Phys. Chem., 72:3683-3684.

Perry, E. A., Gieskes, J. M., and Lawrence, J. R., 1976. Mg, Ca, and ${ }^{18} \mathrm{O} /{ }^{16} \mathrm{O}$ exchange in the sediment-pore water system, Hole 149 , DSDP. Geochim. Cosmochim. Acta, 40:413-423. 
Sayles, F. L., Manheim, F. T., and Waterman, L. S., 1972. Interstitial water studies on small core samples, Leg 11. In Hollister, C. D., Ewing, J. I., et al., Init. Repts. DSDP, 11: Washington (U.S. Govt. Printing Office), 997-1008.

Shipley, T. H., and Didyk, B. M., 1982. Occurrence of methane hydrates offshore Southern Mexico. In Watkins, J. S., Moore, T. C., et al., Init. Repts. DSDP, 66: Washington (U.S. Govt. Printing Office), 547-556.

Shipley, T. H., Houston, M. H., Buffler, R. T., Shaub, F. J., McMillenick, J., Ladd, J. W., and Worzel, J. L., 1979. Seismic evi- dence for widespread possible gas hydrate horizons on continental slopes and rises. Am. Assoc. Pet. Geol. Bull., 63:2204-2213.

Trofimuk, A. A., Cherskiy, N. V., and Tsarev, V. P., 1974. Mechanisms for fractionation of isotopes of water and gas in crustal zones of hydrate formation. Doklady Akad. Nauk. SSSR, 215: $1226-1229$.

Tucholke, B., Bryan, G. M., and Ewing, J., 1977. Gas-hydrate horizons detected in seismic profiler data from the western North Atlantic. Am. Assoc. Pet. Geol. Bull., 61:698-707. 